\title{
Behaviour of physicochemical and microbiological characteristics of vertical flow constructed wetland substrate after treating a mixture of urban and olive mill wastewaters
}

\author{
Ayoub El Ghadraoui ${ }^{1,2,3} \cdot$ Naaila Ouazzani $^{1,2} \cdot$ Chaima Saf $^{1,2} \cdot$ Abdelaali Ahmali $^{1,2}$ Abdessamed Hejjaj $^{2}$. \\ Faissal Aziz ${ }^{1,2} \cdot$ Massimo Del Bubba $^{3} \cdot$ Laila Mandi $^{1,2}$ (1)
}

Received: 16 February 2021 / Accepted: 9 June 2021 / Published online: 16 June 2021

(C) The Author(s), under exclusive licence to Springer-Verlag GmbH Germany, part of Springer Nature 2021

\begin{abstract}
The aim of the current work is to evaluate the effect of a mixture of olive mill wastewater (OMWW) and urban wastewater (UW) on constructed wetland (CW) substrate physicochemical parameters, and to study the abundance and behaviour of microbial community at different depths. In this regard, substrate samples were investigated at three depth levels $(0-10 \mathrm{~cm}, 10-20 \mathrm{~cm}$ and 20-30 cm) inside a pilot scale CW treating the mixture. In order to compare the obtained results with the conventional case, a control (CW pilot plant treating only UW) was implemented. Result shows that an increase in electrical conductivity (from 0.134 to $0.222 \mathrm{mS} / \mathrm{cm}$ in $0-10 \mathrm{~cm}$ and from 0.131 to $0.283 \mathrm{mS} / \mathrm{cm}$ in $10-20 \mathrm{~cm}$ ), total dissolved salts (from 65.45 to $108.67 \mathrm{mg} / \mathrm{kg}$ in 0 $10 \mathrm{~cm}$ and from 64.33 to $135.3 \mathrm{mg} / \mathrm{kg}$ in $10-20 \mathrm{~cm}$ ), total organic carbon (from 0.86 to $6.84 \%$ ), total nitrogen (from $0.1 \mathrm{mg} / \mathrm{kg}$ to $0.45,0.43$ and $0.41 \mathrm{mg} / \mathrm{kg}$, in $0-10 \mathrm{~cm}, 10-20 \mathrm{~cm}$ and $20-30 \mathrm{~cm}$ respectively) and $\mathrm{C} / \mathrm{N}$ ratio take place in the substrate after the treatment of the mixture. As for the microbiological parameters, treating the mixture in a $\mathrm{CW}$ results in an increase in the yeast and fungi which may optimize the biodegradation of compounds such as polyphenols that are non-easily degraded.
\end{abstract}

Keywords Constructed wetland - Substrate $\cdot$ Physicochemical characteristics $\cdot$ Microbiological characteristics $\cdot$ Polyphenols · Olive mill wastewater

\section{Introduction}

Olive oil production is an important agro-industrial activity especially in Mediterranean countries (Elmansour et al. 2020; Bruzzoniti et al. 2020). The most important olive oilproducing countries are Spain, Italy, Greece and Turkey, followed by Tunisia, Portugal, Morocco and Algeria (Paraskeva and Diamadopoulos 2006). Worldwide production of olive oil was estimated in 2002 of about 2.5 million tons,

Responsible Editor: Alexandros Stefanakis

Laila Mandi

mandi@uca.ac.ma

1 Laboratory of Water, Biodiversity and Climate Change, Faculty of Sciences Semlalia, University Cadi Ayyad, Marrakech, Morocco

2 National Centre for Studies and Research on Water and Energy (CNEREE), University Cadi Ayyad, Marrakech, Morocco

3 Department of Chemistry, University of Florence, Sesto Fiorentino, Florence, Italy the majority of which is produced in Mediterranean region (Galanakis 2017). This production is in constant growth responding to a dramatic increasing in olive oil consumption mainly by non-producing countries (Saadi et al. 2007). During the process of olive oil extraction, different by-products are produced such as olive pomace and olive mill wastewater (OMWW). OMWW is generated in considerable volumes during the process of olive oil extraction: over 30 million $\mathrm{m}^{3}$ per year (Barbera et al. 2013). OMWW characteristics and composition could change depending on the multiple factors such as origin, maturity of the fruit and extraction method (Ben Sassi et al. 2006). However, in general, OMWW is a dark brown effluent, characterized by an acidic $\mathrm{pH}$, a very high electrical conductivity (EC), high organic load content, high content of polyphenols and high concentrations of fats, oils and greases (El Ghadraoui et al. 2020; Galanakis 2017; Stefanakis et al. 2014). OMWW discharge without treatment could affect the environment in its different matrixes. In water, OMWW could cause discolouring rivers and streams, decreasing of dissolved oxygen and eutrophication. In soil, the spreading of OMWW could modify the physical parameters 
including porosity, aggregate stability, water retention and hydraulic conductivity and chemical parameters including $\mathrm{pH}, \mathrm{EC}$, total phenols and available $\mathrm{N}, \mathrm{P}$ and $\mathrm{K}$ (Barbera et al. 2013). Decrease in soil $\mathrm{pH}$, increased salinity and high phenol concentrations were observed after OMWW application (Chatzistathis and Koutsos 2017). Many works were devoted to the study of the impact of OMWW on soil microbiological activity such as respiration and bacterial and fungal populations (Chatzistathis and Koutsos 2017; Chehab et al. 2019; Meftah et al. 2019). The presence of high concentrations of certain OMWW constituents such as polyphenols may induce to an antimicrobial effect on some microbial groups and phytotoxic effect of the soil (Barbera et al. 2013; Ayed et al. 2005). Polyphenols can also have phytotoxic effect towards plants (Ahmali et al. 2020). On the other hand, the increasing of $\mathrm{pH}, \mathrm{EC}$ and enrichment of soil by carbon and some nutrients such as nitrogen, phosphorus and potassium after OMWW spreading could increase the concentration of microbial groups such as fungi, yeast and actinomycetes (Chehab et al. 2019; El Hassani et al. 2020). As a wastewater, OMWW must be treated before being discharged. Different treatment methods have been studied in lab and in large scale including physical (dilution, filtration, evaporation, sedimentation and centrifugation), biological (activated sludge) and physicochemical (flocculation, precipitation, adsorption, chemical oxidation, ion exchange and coagulation) treatments. However, these treatments were either not able to reduce organic loads and toxicity to acceptable limits or are relatively expensive as energy or large quantities of chemicals are required (Pelendridou et al. 2014; Paraskeva and Diamadopoulos 2006; Mantzavinos and Kalogerakis 2005; Galanakis 2017). Different biological treatments were also studied such as microorganism treatment, aerobic and anaerobic bioreactor, composting and CWs (Achak et al. 2009, 2019; Ouzounidou et al. 2010; Muktadirul Bari Chowdhury et al. 2013; Paraskeva and Diamadopoulos 2006; Mantzavinos and Kalogerakis 2005). Thanks to its low construction and operation costs, the environmental benefits and the involvement of biological, chemical and physical phenomena, the CW was recently applied for the treatment of diverse types of wastewaters, including the most polluted ones such as industrial tannery wastewater (Tiglyene et al. 2005; Calheiros et al. 2007; Saeed et al. 2012), pulp and paper industry wastewater (Knight et al. 2000), acid mine drainage wastewater (Kleinmann and Girts 1987), swine wastewater (Li et al. 2020), industrial dairy wastewater (Yazdani and Golestani 2019), wine wastewater (Laura et al. 2021) and OMWW (Herouvim et al. 2011; Michailides et al. 2015; Kapellakis et al. 2012; Tatoulis et al. 2017; Achak et al. 2019; Del Bubba et al. 2004; El Ghadraoui et al. 2020). In CW, the major part of the treatment occurs in the substrate, also known as media, support matrix/material or filling material (Wang et al. 2018). Conventional substrates, such as sand, gravel and soil, are mainly used in order to support the plants in CWs with marginal function on nutrient (especially phosphorus) and some specific pollutant removal (Wang et al. 2018; Zhu et al. 2011). In the recent years, novel materials such as pozzolan (El Ghadraoui et al. 2020), tire chips (Chyan et al. 2013), oyster shells (Park and Polprasert 2008) and construction wastes (Shi et al. 2017) have proven their efficiency in the increase of the treatment capacity and the prevention from clogging issues in constructed wetlands.

To the best of our knowledge, the current work is the first documenting the behaviour of both microbiological and physicochemical characteristics of vertical flow $\mathrm{CW}$ substrate after treating a mixture of urban wastewater (UW) and olive mill wastewaters (OMWW). Based on the aforementioned considerations, the aim of this work is to evaluate the behaviour of microbiological and physicochemical proprieties of vertical flow constructed wetland with pozzolan layer treating a mixture of UW and OMWW.

\section{Material and methods}

\section{Experimental site}

The treatment study was conducted for a period of over 1 year in the botanic garden inside the Faculty of Science SemlaliaMarrakech (Morocco). In this area, two pilot vertical flow CWs were established (Fig. 1).

The pilots were built from a polyvinyl chloride circular tank (height $0.60 \mathrm{~m}$ and surface area $0.24 \mathrm{~m}^{2}$ ) and filled from the top with $30 \mathrm{~cm}$ of sand $(0.25 / 0.40 \mathrm{~mm})$ as infiltration layer followed by $10 \mathrm{~cm}$ of pozzolan $(5 / 20 \mathrm{~mm})$ as transition layer and $10 \mathrm{~cm}$ of gravel $(20 / 40 \mathrm{~mm})$ as drainage layer. The full details are reported in the previous work (El Ghadraoui et al. 2020). Both pilots were planted with Phragmites australis. In the bottom of the tanks, a drain was installed in order to collect the water after its treatment. Both influents and effluents were monitored for a period of over 1 year in order to highlight the efficiency of the two CWs. The first pilot (Fig. 1a) was feed with a mixture of OMWW and UW (Mixture) with the following proportions, $89.9 \%$ organic load of OMWW and $10.1 \%$ of UW (El Ghadraoui et al. 2020). The second pilot (Fig. 1b) was fed with only UW. Both pilots were fed using peristaltic pump according to the following program: 1-day alimentation and 2-day rest respecting an organic loading rate of $366 \mathrm{~g}$ of $\mathrm{COD} / \mathrm{m}^{2} /$ day.

\section{Sampling}

\section{Liquid sampling}

OMWW used in this study was collected from an extraction unit of olive oil working with a traditional extraction system 
Fig. 1 Diagram of the pilot scaleconstructed wetlands (a)

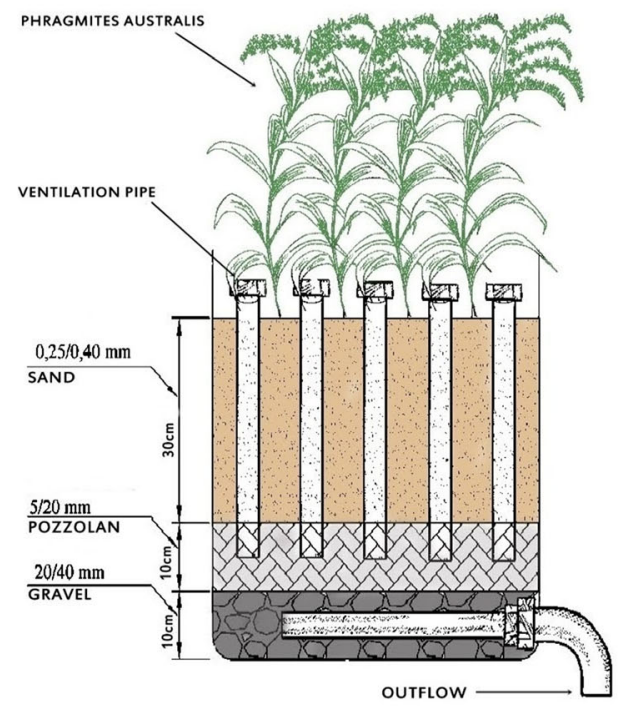

Surface area: $0,24 \mathrm{~m}^{2}$ Influent: Mixture of OMWW and UW Organic load used: $366 \mathrm{~g} \mathrm{COD} / \mathrm{m}^{2} / \mathrm{d}$ Hydraulic load used $: 60 \mathrm{~L} / \mathrm{m}^{2} / \mathrm{d}$ (b)

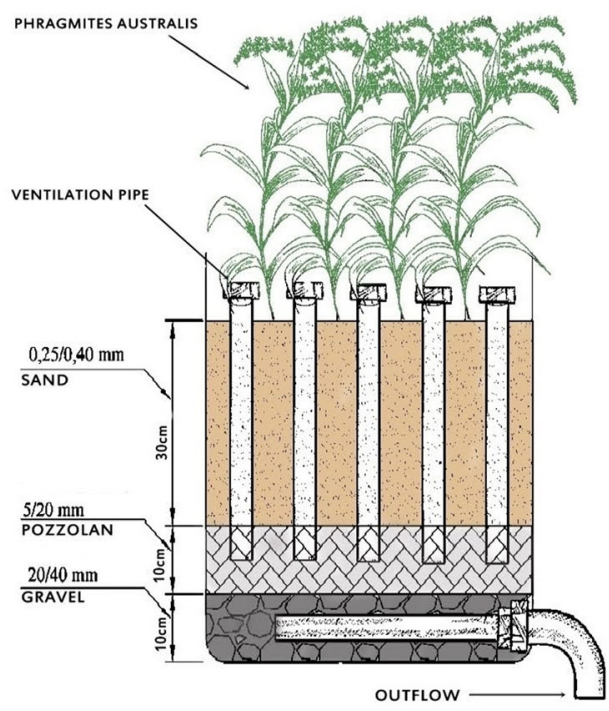

Surface area: $0,24 \mathrm{~m}^{2}$ Influent: UW Organic load used: $366 \mathrm{~g} \mathrm{COD} / \mathrm{m}^{2} / \mathrm{d}$ Hydraulic load used : $703 \mathrm{~L} / \mathrm{m}^{2} / \mathrm{d}$ (press) located in Rass El Ain $50 \mathrm{~km}$ on the N8 of Marrakech City (Morocco). The sampling was achieved during the month of February 2016. The UW used to perform the mixture is collected from the inlet of Marrakech wastewater treatment plant (activated sludge) each week in order to preserve the biomass present in that wastewater.

\section{Solid sampling}

One sampling campaign was conducted after 1 year of the system functioning. Three samples of sand from the $\mathrm{CW}$ treating the mixture (S-Mixture) and sand from the $\mathrm{CW}$ treating UW (S-UW) were collected using a soil sampler probe at 3 different depths $(0-10 \mathrm{~cm}, 10-20 \mathrm{~cm}$ and $20-$ $30 \mathrm{~cm}$ ) and compared to raw sand (RS) in order to evaluate the effect of the mixture and UW on both physicochemical and microbiological parameters inside the CWs.

\section{Influent and effluent analysis}

EC, $\mathrm{pH}$ and total dissolved salts (TDS) were measured at room temperature with a multi-probe parameter type (HANNA HI 9829, Romania). Total suspended solids (TSS) were measured following (T90-105, AFNOR 1997) using a filtration membrane $(0.45 \mu \mathrm{m}), \mathrm{COD}$ determination is made by the potassium dichromate method according to AFNOR standard (T 90-101, AFNOR 1988). Total phosphorus (TP) was performed following the protocol (T90-023, AFNOR 1982). Ortho-phosphorus $\left(\mathrm{PO}_{4}{ }^{3-}\right)$ analysis is performed according to the protocol (T90-022, AFNOR 1982); ammonia
$\left(\mathrm{NH}_{4}{ }^{+}\right)$is determined by a colorimetric technique according to the AFNOR standard (T90-015, AFNOR 2000); nitrites $\left(\mathrm{NO}_{2}{ }^{-}\right)$are determined after diazotization according to (T90013, AFNOR 1985); nitrates $\left(\mathrm{NO}_{3}{ }^{-}\right)$are reduced to nitrites by passage over a copper cadmium column (Rodier et al. 2009). Measurement of sulphate is carried out according to Rodier et al. (2009).

\section{Substrate physicochemical analysis}

$\mathrm{EC}$ and $\mathrm{pH}$ were determined using a multi-parameter instrument (HANNA HI 9829, Romania) by mixing $10 \mathrm{~g}$ of extracted sand with $50 \mathrm{ml}$ of distilled water. Total organic carbon (TOC) was determined following the Anne method (Aubert 1978) which consisted on the oxidation of the organic matter carbon by potassium dichromate in sulphuric medium until release of $\mathrm{CO}_{2}$; the excess of dichromate is drawn by a solution of iron sulphate and ammonium (Mohr salt) in the presence of an indicator diphenylamine. Total nitrogen (TN) was quantified using the method (ISO 11261, AFNOR 1995), and the sample is mineralized in sulphuric acid medium in the presence of copper (II) and a catalyst (titanium oxide). Under the conditions of mineralization, organic nitrogen is recovered in the ammonium form. The ammonium ions are converted to ammonia by passing in an alkaline medium. $\mathrm{NH}_{3}$ is driven to the water vapour and the condensate collected dose volumetric acid/base titration.

For the analysis of polyphenols at different depths, the Macheix method (Macheix et al. 2018) was adapted to determine phenolic compounds. Substrate sample of $10 \mathrm{~g}$ each was 
shaken in $20 \mathrm{ml}$ cold methanol $(80 \% \mathrm{v} / \mathrm{v})$ for $15 \mathrm{~min}$ and the mixture was centrifuged for $3 \mathrm{~min}$ at $5000 \mathrm{rpm}$ at $4^{\circ} \mathrm{C}$. This step was repeated three times before the supernatants were evaporated to remove methanol. A solution of ammonium sulphate $(40 \% \mathrm{v} / \mathrm{v})$ was added to the extract followed by meta-phosphoric acid solution of $20 \%(1 / 10 \mathrm{v} / \mathrm{v})$. This phase was followed by depigmentation and defatting of with petroleum ether (v/2). The extract was purified by ethylene acetate (v/v) and evaporated to dryness at $35^{\circ} \mathrm{C}$ with a rotary evaporator and the residue was recovered in $2 \mathrm{ml}$ of Grade HPLC pure methanol before being analysed using the KNAUER HPLC model AZURA (Berlin, Germany).

\section{Substrate bacteriological analysis}

Microbial counts of $\mathrm{CW}$ substrates initially focused on the enumeration of total flora, yeasts and fungi. The microbiological analyses of samples were carried out upon receipt in the laboratory in order to avoid any modification of the initial microbial concentration. After homogenization of sand samples, a series of dilutions in sterile physiological saline is performed $(0.9 \% \mathrm{NaCl})$. A volume of $0.1 \mathrm{ml}$ of the appropriate dilution is plated on Petri dishes containing the appropriate agar medium at the rate of three repetitions by dilution. Nutrient agar (BK185HA, Beauvais, FR) is used at pH 7 for total flora community, and the incubation of spread boxes is carried out at $37^{\circ} \mathrm{C}$ for $24 \mathrm{~h}$. Sabouraud dextrose agar (L007492, Maryland, USA) culture medium is used to determine fungi to which $25 \mu \mathrm{g} / \mathrm{ml}$ of Chloramphenicol (IB02080, Dubuque, USA) was added as antibiotics to prevent microbial growth. The incubation of the inoculated dishes is carried out at $30{ }^{\circ} \mathrm{C}$ for $3-7$ days. For yeast, the culture medium used is Peptone Dextrose Agar (242720, Maryland, USA), and incubation is carried out at $30^{\circ} \mathrm{C}$ for $48-72 \mathrm{~h}$.

\section{Statistical analysis}

Statistical analyses were done using statistical software SPSS Statistics 20. Three repeats were performed in this study. They have been expressed in mean \pm standard deviation, using analysis of variance ANOVA (Analysis of Variance). Pearson correlation and t test with $\mathrm{P}=0.05$ were also used.

\section{Results and discussion}

The study was carried out in the spring period characterized by a temperature between 10 and $22^{\circ} \mathrm{C}$ in March and between 18 and $32^{\circ} \mathrm{C}$ in June. This period was characterized by no rain (Fig. 2).

\section{Influent and effluent characterization}

Table 1 shows the physicochemical proprieties of the studied wastewaters. OMWW is acidic $(\mathrm{pH}=5.01)$, characterized by a high conductivity $28.23 \mathrm{mS} / \mathrm{cm}$, a high organic content evaluated in terms of COD $264.05 \mathrm{~g} / \mathrm{l}$ and high content of total suspended solids of $2066 \mathrm{mg} / \mathrm{l}$.

The concentration of polyphenols is particularly high of $8.73 \mathrm{~g} / \mathrm{l}$. The characteristics of OMWW are often variable and depend on several factors (e.g. olive variety, extraction method, fruit maturation). However, similar results have been reported by several authors in the literature (Azbar et al. 2004; Aissam 2003; Piotrowska et al. 2011; Aktas et al. 2001).

The concentration of OMWW was decreased by using UW as diluent. The $\mathrm{pH}$ went from 5.01 to 7.33 , conductivity decreased by $84 \%$, TSS decreased by $72 \%$, COD decreased by $96 \%$ and total polyphenols decreased by $98 \%$. The practical results in Table 1 can be slightly different from the theoretical values calculated based on a dilution factor of 9:1 (UW: OMWW). This lack of correlation is basically due to the use of large volume materials (usually less precise) for the preparation of important volumes of the mixture. Since the OMWW is highly concentrated the slightest drop could change drastically the concentration especially for COD. This would not impact the results from the $\mathrm{CW}$ pilot as for each campaign both the influent and the effluent were analysed.

The aim of using UW for the dilution of OMWW and not tap water (as it is mostly used in literature) is to simultaneously treat two types of sewage at once and to increase the efficiency of the system by providing a bacterial flora that will optimize the operation of the $\mathrm{CW}$, so through this method we are witnessing a conservation of water and energy resources.

\section{Treatment efficiency}

The removal efficiency of the $\mathrm{CW}$ pilot towards the mixture is well detailed in the author's previous work (El Ghadraoui et al. 2020). Both pilot units were monitored for a period of over 1 year in order to demonstrate their performance regarding the treatment of different influents (Mixture and UW). The obtained results (Table 2) show that the CW pilot unit treating the mixture presents a remarkable performance towards different pollutants despite the complexity and the high organic load of the mixture.

The pilot treating the mixture managed to remove $99 \%$, $91 \%, 89 \%, 94 \%, 94 \%, 58 \%, 92 \%$ and $95 \%$ for TSS, COD, total polyphenols, $\mathrm{PO}_{4}{ }^{3-}, \mathrm{P}, \mathrm{SO}_{4}{ }^{2-}, \mathrm{NO}_{2}{ }^{-}$and $\mathrm{NH}_{4}{ }^{+}$respectively (El Ghadraoui et al. 2020). The pilot treating UW allowed to determine the following removal efficiencies; $99 \%, 85 \%, 90 \%, 91 \%, 46 \%, 89 \%, 87 \%$ for TSS, COD, $\mathrm{PO}_{4}{ }^{3-}, \mathrm{P}, \mathrm{SO}_{4}{ }^{2-}, \mathrm{NO}_{2}{ }^{-}$and $\mathrm{NH}_{4}{ }^{+}$respectively. Similar or less efficient removal performances were reported by the authors regarding the treatment of OMWW+UW mixture by $\mathrm{CW}$. For 
Fig. 2 Climatic diagram representing the rainfall, maximum and minimum air temperature during the experimental period

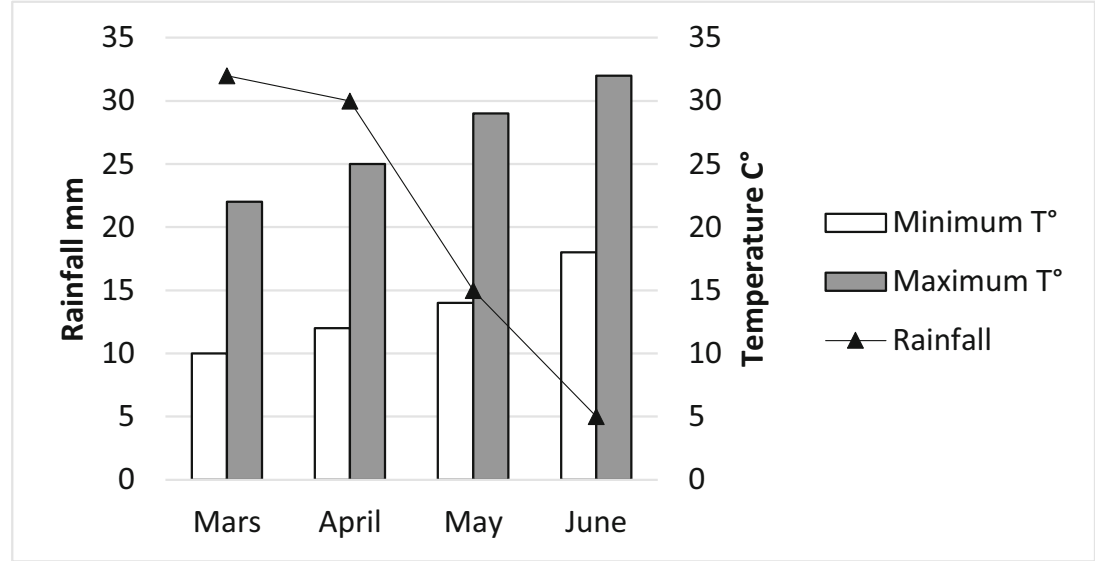

TSS, a removal efficiency of $70 \%$ was reported by Achak et al. (2011); several authors have reported a COD removal reaching 73\% (Yalcuk et al. 2010; Herouvim et al. 2011); for polyphenols, the performances reported in literature were around 70\% (Kapellakis et al. 2008; Herouvim et al. 2011) and $95 \%$ (Achak et al. 2011); for $\mathrm{NH}_{4}{ }^{+}$, the removal attained 75\% (Achak et al. 2011) and 49\% (Yalcuk et al. 2010). An elimination of 95\% (Herouvim et al. 2011) and 87\% (Yalcuk et al. 2010) were reported regarding the phosphorus concentration.

\section{Substrate physicochemical characteristics}

The result of RS, S-Mixture and S-UW physicochemical analyses are shown in Table 3.

$R S$ : Raw sand; $S-U W$ : sand from $C W$ treating $U W ; S-$ Mixture sand from $C W$ treating $O M W W$; EC: electrical

Table 1 Physicochemical characteristics of urban wastewater (UW), crude olive mill wastewater (OMWW) and a mixture of olive mill wastewater and urban wastewater (Mixture) $(89.9 \%$ and $10.1 \%$ organic load, respectively) (mean of 3 replicates \pm standard deviation) (El Ghadraoui et al. 2020)

\begin{tabular}{llll}
\hline Parameters & UW & OMWW & Mixture \\
\hline $\mathrm{pH}$ & 7.07 & 5.01 & 7.26 \\
$\mathrm{EC}, \mathrm{mS} / \mathrm{cm}$ & 2.21 & 28.23 & 4.445 \\
$\mathrm{TDS}, \mathrm{g} / \mathrm{l}$ & 0.32 & 22.10 & 2.22 \\
$\mathrm{COD}, \mathrm{g} / \mathrm{l}$ & $0.51 \pm 0.41$ & $264.05 \pm 11.49$ & $6.10 \pm 0.54$ \\
$\mathrm{TSS}, \mathrm{mg} / \mathrm{l}$ & $228.33 \pm 13.5$ & $2066 \pm 11.26$ & $577.78 \pm 13.87$ \\
$\mathrm{Total} \mathrm{polyphenols,} \mathrm{mg} / 1$ & $0.01 \pm 0.004$ & $8732 \pm 0.43$ & $131 \pm 3.27$ \\
$\mathrm{PO}_{4}{ }^{3-}, \mathrm{mg} / 1$ & $0.82 \pm 0.06$ & $31.14 \pm 0.65$ & $9.45 \pm 0.46$ \\
$\mathrm{P}_{\mathrm{mg}} / \mathrm{l}$ & $0.95 \pm 0.06$ & $41.61 \pm 4.37$ & $10.19 \pm 0.48$ \\
$\mathrm{NH}_{4}+, \mathrm{mg} / 1$ & $12.95 \pm 0.52$ & $6.33 \pm 0.30$ & $12.40 \pm 0.94$ \\
$\mathrm{NO}_{3-}, \mathrm{mg} / 1$ & $0.04 \pm 0.01$ & $1.32 \pm 0.05$ & $0.22 \pm 0.04$ \\
$\mathrm{NO}_{2-}, \mathrm{mg} / \mathrm{l}$ & $1.25 \pm 0.08$ & $96.23 \pm 9.41$ & $2.04 \pm 0.08$ \\
$\mathrm{SO}_{4}{ }^{2-}, \mathrm{mg} / 1$ & $136.6 \pm 12.58$ & $1320 \pm 0.05$ & $232.6 \pm 33.99$ \\
\hline
\end{tabular}

conductivity; TDS: total dissolved salts; TOC: total organic carbon; TN: total nitrogen; $C / N$ : carbon/nitrogen ratio

The $\mathrm{pH}$ of RS was neutral (7.27). The monitoring of substrate characteristic behaviour in different depths helps to conclude that the $\mathrm{pH}$ remains always neutral in both pilots (Fig. 3A). This is probably due to the similarity of UW and the mixture $\mathrm{pH}$ (see Table 1). These results are similar to those reported by several authors stipulating that the $\mathrm{pH}$ remains unchangeable in the sand after the application of OMWW. Piotrowska et al. (2011) reported values of 8.6 and 8.7 for raw substrate and for the substrate after OMWW application respectively after 42 days of study. Meftah et al. (2019) reported values of 7.56 and 7.36 for raw substrate and for the substrate after OMWW application respectively. The authors have also demonstrated that in the case of a highly acidic or high applied load of OMWW, a slight decrease of $\mathrm{pH}$ is noticed. However, this decrease occurred only in short term as after few weeks, the $\mathrm{pH}$ return to neutral (Piotrowska et al. 2011; Meftah et al. 2019).

Table 3 and Fig. 3-B show that the treatment of the mixture by the $\mathrm{CW}$ have resulted in an increase of EC in the first two layers $(0-10$ and $10-20 \mathrm{~cm})$, as EC increased from 0.134 to

Table 2 Removal efficiency achieved by the investigated pilots (El Ghadraoui et al. 2020)

\begin{tabular}{lll}
\hline Parameters & Pilots & \\
\cline { 2 - 3 } & Mixture pilot (\%) & UW pilot (\%) \\
\hline $\mathrm{TSS}$ & 99 & 99 \\
$\mathrm{COD}$ & 91 & 85 \\
Total polyphenols & 89 & - \\
$\mathrm{PO}_{4}{ }^{-}$ & 94 & 90 \\
$\mathrm{P}$ & 94 & 91 \\
$\mathrm{SO}_{4}{ }^{2}-$ & 58 & 46 \\
$\mathrm{NO}_{2-}$ & 92 & 89 \\
$\mathrm{NH}_{4}{ }^{-}$ & 95 & 87 \\
\hline
\end{tabular}


Table 3 Substrate physicochemical characteristics per kg of dry sand (mean of 3 replicates \pm standard deviation)

\begin{tabular}{|c|c|c|c|c|}
\hline Parameters & Unit & $\mathrm{RS}$ & S-UW & S-Mixture \\
\hline \multicolumn{5}{|l|}{ Layer $0-10 \mathrm{~cm}$} \\
\hline $\mathrm{pH}$ & & $7.27 \pm 0.14$ & $7.24 \pm 0.21$ & $7.28 \pm 0.14$ \\
\hline $\mathrm{EC}$ & $\mathrm{mS} / \mathrm{cm}$ & $0.13 \pm 0.01$ & $0.18 \pm 0.01$ & $0.22 \pm 0.01$ \\
\hline TDS & $\mathrm{mg} / \mathrm{kg}$ & $65.45 \pm 1.3$ & $89.36 \pm 2.7$ & $108.67 \pm 4.34$ \\
\hline Total polyphenols & $\mathrm{mg} / \mathrm{kg}$ & $0.06 \pm 0.01$ & $0.9 \pm 0.05$ & $2.1 \pm 0.23$ \\
\hline $\mathrm{TN}$ & $\mathrm{mg} / \mathrm{kg}$ & $0.11 \pm 0.01$ & $0.14 \pm 0.01$ & $0.45 \pm 0.06$ \\
\hline TOC & $\%$ & $0.64 \pm 0.07$ & $0.97 \pm 0.11$ & $6.84 \pm 0.75$ \\
\hline $\mathrm{C} / \mathrm{N}$ & & $5.81 \pm 0.7$ & $6.92 \pm 0.83$ & $15.2 \pm 1.82$ \\
\hline \multicolumn{5}{|l|}{ Layer $10-20 \mathrm{~cm}$} \\
\hline $\mathrm{pH}$ & & $7.24 \pm 0.14$ & $7.27 \pm 0.21$ & $7.31 \pm 0.14$ \\
\hline $\mathrm{EC}$ & $\mathrm{mS} / \mathrm{cm}$ & $0.13 \pm 0.01$ & $0.23 \pm 0.01$ & $0.28 \pm 0.01$ \\
\hline TDS & $\mathrm{mg} / \mathrm{kg}$ & $64.33 \pm 1.3$ & $\begin{array}{c}100.67 \\
\pm 3.02\end{array}$ & $135.3 \pm 5.41$ \\
\hline Total polyphenols & $\mathrm{mg} / \mathrm{kg}$ & $0.05 \pm 0.01$ & $0.8 \pm 0.04$ & $1.9 \pm 0.2$ \\
\hline $\mathrm{TN}$ & $\mathrm{mg} / \mathrm{kg}$ & $0.09 \pm 0.01$ & $0.13 \pm 0.01$ & $0.43 \pm 0.06$ \\
\hline TOC & $\%$ & $0.63 \pm 0.07$ & $0.88 \pm 0.1$ & $6.41 \pm 0.7$ \\
\hline $\mathrm{C} / \mathrm{N}$ & & $5.72 \pm 0.68$ & $6.76 \pm 0.81$ & $14.9 \pm 1.8$ \\
\hline \multicolumn{5}{|l|}{ Layer $20-30 \mathrm{~cm}$} \\
\hline $\mathrm{pH}$ & & $7.22 \pm 0.14$ & $7.27 \pm 0.21$ & $7.35 \pm 0.14$ \\
\hline $\mathrm{EC}$ & $\mathrm{mS} / \mathrm{cm}$ & $0.13 \pm 0.01$ & $0.17 \pm 0.01$ & $0.21 \pm 0.01$ \\
\hline TDS & $\mathrm{mg} / \mathrm{kg}$ & $64.29 \pm 1.3$ & $79.33 \pm 2.37$ & $93.67 \pm 3.74$ \\
\hline Total polyphenols & $\mathrm{mg} / \mathrm{kg}$ & $0.03 \pm 0.01$ & $0.7 \pm 0.04$ & $1.6 \pm 0.2$ \\
\hline $\mathrm{TN}$ & $\mathrm{mg} / \mathrm{kg}$ & $0.06 \pm 0.01$ & $0.12 \pm 0.01$ & $0.41 \pm 0.06$ \\
\hline TOC & $\%$ & $0.59 \pm 0.07$ & $0.8 \pm 0.096$ & $5.88 \pm 0.64$ \\
\hline $\mathrm{C} / \mathrm{N}$ & & $5.36 \pm 0.64$ & $6.66 \pm 0.8$ & $14.34 \pm 1.72$ \\
\hline
\end{tabular}

$0.222 \mathrm{mS} / \mathrm{cm}$ in $0-10 \mathrm{~cm}$ and from 0.131 to $0.283 \mathrm{mS} / \mathrm{cm}$ in 10-20 cm. TDS mean concentrations were also increased in the first two layers as the concentration went from 65.45 to $108.67 \mathrm{mg} / \mathrm{kg}$ in $0-10 \mathrm{~cm}$ and from 64.33 to $135.3 \mathrm{mg} / \mathrm{kg}$ in 10-20cm (Fig. 3-C). The same results were reported by several authors (Di Serio et al. 2008; Magdich et al. 2016; Barbera et al. 2013; Karpouzas et al. 2010) demonstrating that EC and TDS in the substrate in which OMWW were applied increases in the first $20 \mathrm{~cm}$. This increase in EC and TDS is undoubtedly the results of the physical trapping of salts in sand layers (Corwin and Yemoto 2020). However, it is observed that the conductivity and TDS is slightly lower in the 20-30 cm layer, since EC decreased from 0.283 to $0.216 \mathrm{mS} /$ $\mathrm{cm}$ and TDS from 135.3 to $93.67 \mathrm{mg} / \mathrm{kg}$. The same results were reported by Meftah et al. (2019) demonstrating that the EC and TDS decrease starting from $20 \mathrm{~cm}$. The observed increase in conductivity and in total dissolved salts remains temporary over time (Chiesura et al. 2005).

The results in Table 3 and Fig. 3-E demonstrate also the behaviour of TOC inside the different pilots. It shows that raw sand is very poor in total organic carbon $\approx 0.64 \%$. It was also observed that after the treatment of the mixture in the $\mathrm{CW}$, the concentration of TOC has increased significantly as the value jumped from 0.86 to $6.84 \%$ in the first layer $(0-10 \mathrm{~cm})$. This rise is undoubtedly due to the high organic load applied on the pilot (366 g COD $/ \mathrm{m}^{2} /$ day). The same results were reported by Piotrowska et al. (2011), Di Serio et al. (2008). Figure 3-E shows that the highest concentration of organic matter is located in the first $0-10 \mathrm{~cm}$ layer. This is possibly due to the physical barrier role played by the fine sand which captures the particulate organic matter. Figure 3-E also shows that the concentration of TOC slightly decreases with depth as it went from 6.84 to $6.41 \%$ and $5.88 \%$ respectively in the $10-20-\mathrm{cm}$ and 20-30-cm layers.

According to the results presented in Table 3 and Fig. 3-D, the concentration of total nitrogen has significantly increased after the treatment of the mixture. The measured concentrations in S-Mixture were $0.45,0.43$ and $0.41 \mathrm{mg} / \mathrm{kg}$ of dry sand whereas for RS, the concentrations were $0.11,0.9$ and $0.6 \mathrm{mg} /$ $\mathrm{kg}$ of dry sand respectively for 0-10, 10-20 and 20-30-cm depths. Similar results were reported in the literature as authors have demonstrated that the concentration of nitrogen in the substrate increases when the latter is in contact with OMWW (Piotrowska et al. 2011; Meftah et al. 2019). This significant increase is probably due to the high concentration of nitrogen in the mixture as shown in Table 3.

Data demonstrated in Fig. 3-F show that $\mathrm{C} / \mathrm{N}$ ratio has been increased by a factor of three after the treatment of the mixture 

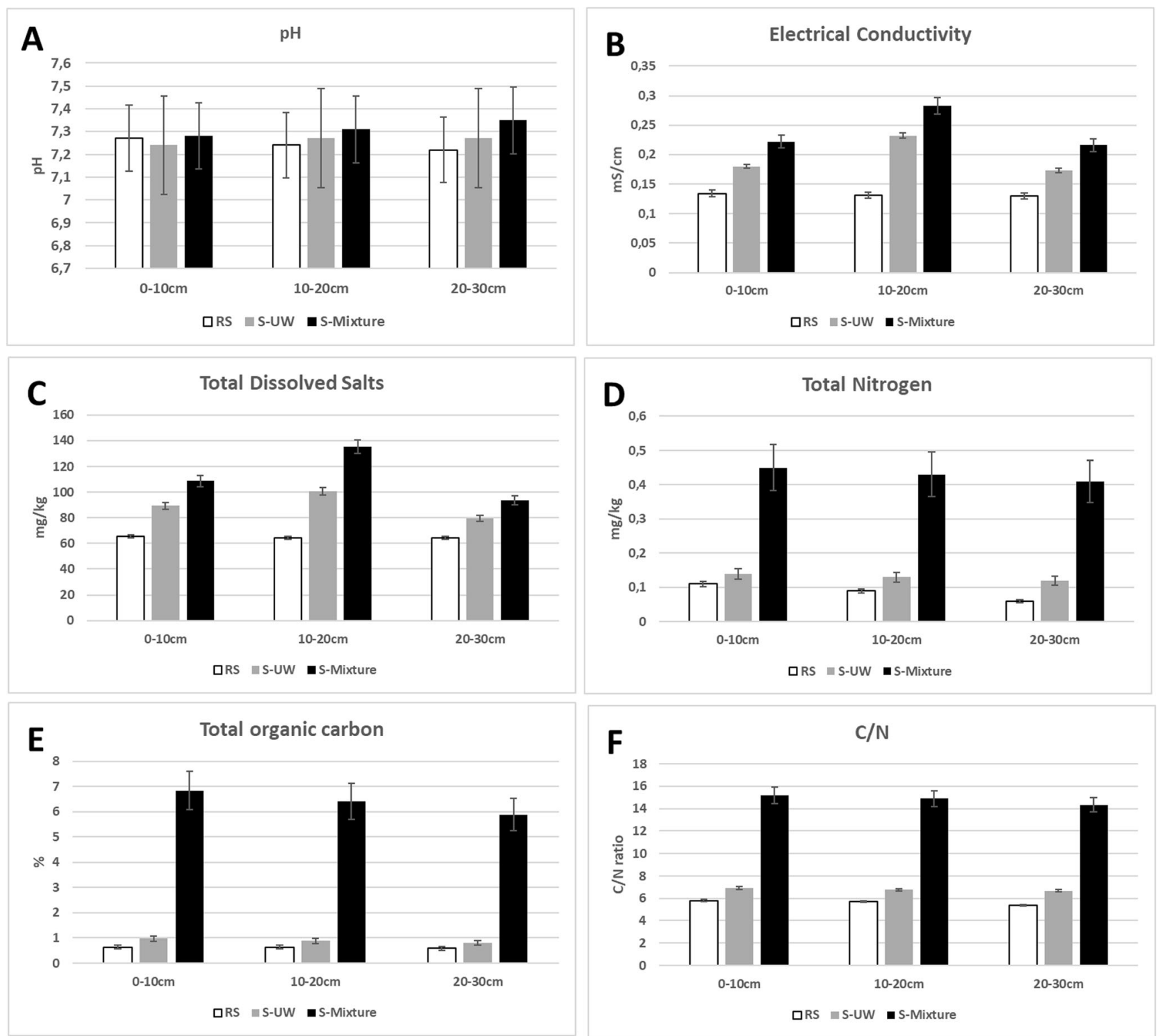

Fig. 3 Physicochemical characteristics of raw sand (RS), sand from CW receiving urban wastewater (S-UW) and sand from CW receiving the mixture (S-Mixture). A-pH, B-Electrical conductivity, C-total dissolved salts, D-Total nitrogen, E-total organic carbon, F-C/N ratio

by the $\mathrm{CW}$, since the value of the $\mathrm{C} / \mathrm{N}$ ratio in the $\mathrm{RS}$ was 5.81 whereas for S-Mixture, $\mathrm{C} / \mathrm{N}$ ratio in the first $0-10-\mathrm{cm}$ layer is 15.2. These results are supported by other studies, as they report that the application of OMWW on a substrate may result in the increase of organic carbon and therefore the increase of the C/N ratio (Paredes et al. 1987; Di Serio et al. 2008; Piotrowska et al. 2011; Barbera et al. 2013). In this study, the highest $\mathrm{C} / \mathrm{N}$ ratio was observed in the first layer $(0-10 \mathrm{~cm})$. The results in Fig. $3-\mathrm{F}$ show that the $\mathrm{C} / \mathrm{N}$ ratio tends to decrease with the increase of depth (Meftah et al. 2019).

For polyphenols, the data show that the concentrations in RS are very low of $0.06,0.05$ and $0.03 \mathrm{~g} / \mathrm{kg}$ of dry sand respectively for $0-10,10-20$ and $20-30 \mathrm{~cm}$ (Table 3 and Fig. 4).

In S-UW, the concentrations of polyphenols are slightly higher than those observed in RS since the values were 0.9 , 0.8 and $0.7 \mathrm{~g} / \mathrm{kg}$ of dry sand respectively for $0-10,10-20$ and 20-30 cm. In S-Mixture, the concentrations of polyphenols were significantly higher compared to RS and S-UW as the concentrations were $2.1,1.9$ and $1.6 \mathrm{~g} / \mathrm{kg}$ of dry sand respectively for $0-10,10-20$ and $20-30 \mathrm{~cm}$ (Table 3 ). The results show also that the concentration of polyphenols decreases with the increase of depth. Similar results were reported by Di Serio et al. (2008) as the authors demonstrated that the concentration of total polyphenols in the substrate increase after the contact with the OMWW. In the same study, the 
Fig. 4 Concentration of total polyphenols in different substrates

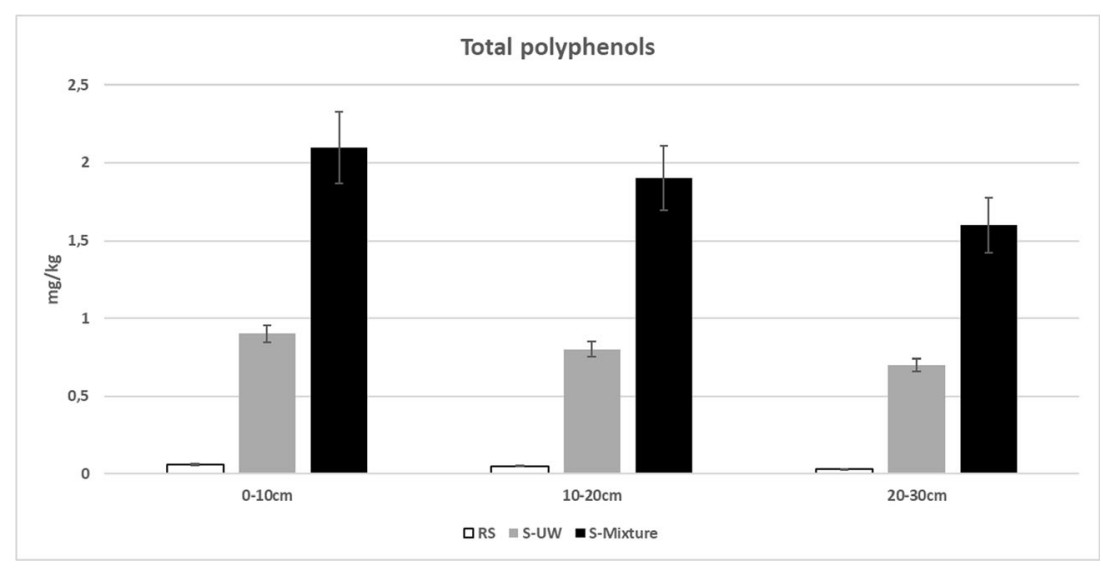

authors have shown that the concentration of polyphenols decreases by the increase of depth. In another work, the author has demonstrated that when OMWW is applied on a substrate, the polyphenol concentration increases and the majority of phenolic compounds are located in the upper layer (Mekki et al. 2007). The same authors have shown that the concentration of polyphenols decreases quickly from 0 to $25 \mathrm{~cm}$ then continued to decrease slightly with depth but remained detectable at $120 \mathrm{~cm}$.

\section{Substrate microbiological proprieties}

Microbial counts were determined in order to compare the total flora, fungi and yeast in the two CW substrates (S-UW and S-Mixture) receiving respectively $\mathrm{UW}$ and the UW/ OMWW mixture. Figure 5 shows that generally speaking for S-UW, a dominance of total flora was observed with a mean concentration of $9.68 \mathrm{E}+06 \mathrm{CFU} / \mathrm{g}$ of dry sand followed by fungi and yeast with a respective mean concentration of 1.29E+04 and 2.49E+04 CFU/g of dry sand.

The same results were found for S-Mixture where total flora was the most dominant group followed by yeast and fungi respectively with the following means concentrations $1.02 \mathrm{E}+07,5.87 \mathrm{E}+06$ and $2.96 \mathrm{E}+05 \mathrm{CFU} / \mathrm{g}$ of dry sand. The application of $\mathrm{T}$ test on microbial diversity for both pilot systems revealed no significant difference between the abundance of total flora in S-UW and S-Mixture $(\mathrm{P}=0.7)$ and fungi ( $\mathrm{P}=0.54)$ whereas the opposite for yeast where the difference is very significant $(\mathrm{P}=0.01)$. The increasing of microbial community was reported by El Hassani et al. (2020) who demonstrated that the abundance of soil total microflora is enhanced after OMWW application. This change in the microbial community was explained by several authors as it could result from the interactions between different factors such as micro environmental changes (lowered oxidative conditions, strong competition for mineral nitrogen and the availability of phenolic compounds) and the selective inhibition of other microbial groups by phenols and altered C-sources (Karpouzas et al. 2010). It has been suggested that the spreading of OMWW impacted the structure of the soil microbial communities by affecting the nutritional status of the soil (Rousidou et al. 2010). The same authors related the changes of microbial community to the modification of soil structure that occurs after the application of OMWW on the substrate.
Fig. 5 Microbiological characteristics of S-UW and SMixture

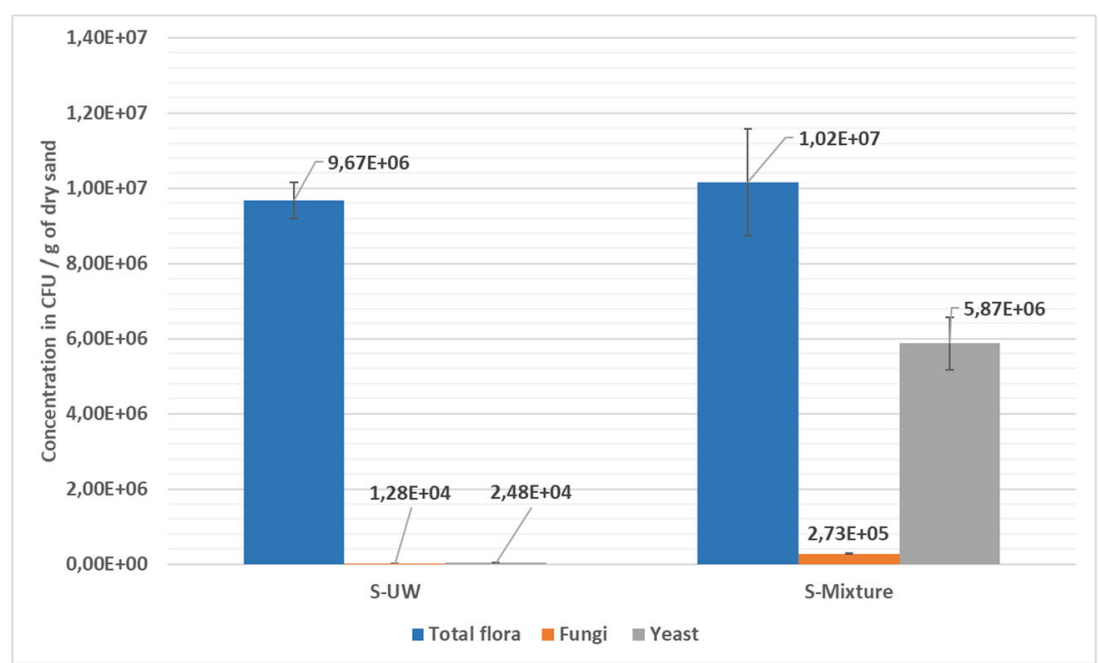


The abundance of actinomycetes, Gram-positive bacteria, fungi and arbuscular mycorrhizal fungi are related to variations with soil total carbon and total nitrogen (Zhao et al. 2019). Therefore, the increasing of total flora community after treatment of the mixture by the $\mathrm{CW}$ has been justified as the physicochemical analysis on S-Mixture have shown an increasing of $\mathrm{pH}, \mathrm{EC}, \mathrm{TDS}, \mathrm{TN}, \mathrm{TOC}$ and $\mathrm{C} / \mathrm{N}$ ratio. In this study, the increasing of fungi and yeast can justify the high performance of the studied $\mathrm{CW}$ regarding the treatment of the mixture (see Table 2) (El Ghadraoui et al. 2020). As it is reported in the literature, these microbial groups are mainly responsible for the degradation of organic fraction especially phenolic compounds (Mutabaruka et al. 2007; Sinsabaugh 2010; Di Serio et al. 2008).

The observed increase of microbial community and especially for yeast can be correlated with removal efficiency as it is reported in the literature that microbial communities such as yeast and fungi are responsible for the removal of organic matter especially the non-easily degradable such as polyphenols. Morillo et al. (2008) studied the bioremediation of OMWW and stated that the increase in the relative fungal/ bacterial ratio was accompanied by high polyphenolic and organic matter reduction. It is also reported in the literature that this microbial groups are mainly responsible for the degradation of organic fraction especially phenolic compounds (Mutabaruka et al. 2007; Sinsabaugh 2010; Di Serio et al. 2008)

Amaral et al. (2010) reported that several microbial strains were tested for their ability to remove organic matter from diluted and undiluted OMWW. The most used were strains of Geotrichum candidum, but other yeast species such as Candida tropicalis, C. rugosa, C. cylindracea, Trichosporon

Table 4 Microbiological characteristics of CW pilot plant substrate receiving urban wastewater (S-UW) and $\mathrm{CW}$ pilot plant receiving the mixture (S-Mixture) at different depths (mean of 3 replicates \pm standard deviation)

\begin{tabular}{llll}
\hline Parameters & Unit & S-UW & S-Mixture \\
\hline & & Layer 0-10cm & \\
Total flora & CFU/g & $(1.39 \pm 0.06) \times 10^{7}$ & $(1.02 \pm 0.07) \times 10^{7}$ \\
Fungi & & $(2.14 \pm 0.1) \times 10^{4}$ & $(3.4 \pm 0.1) \times 10^{5}$ \\
Yeast & & $(3.1 \pm 0.06) \times 10^{4}$ & $(3.43 \pm 0.1) \times 10^{6}$ \\
& & Layer 10-20cm & \\
Total flora & CFU/g & $(9.20 \pm 0.46) \times 10^{6}$ & $(1.35 \pm 0.09) \times 10^{7}$ \\
Fungi & & $(1.45 \pm 0.07) \times 10^{4}$ & $(4.69 \pm 0.14) \times 10^{5}$ \\
Yeast & & $(4.33 \pm 0.08) \times 10^{4}$ & $(1.37 \pm 0.04) \times 10^{7}$ \\
& & Layer 20-30cm & \\
Total flora & CFU/g & $(5.90 \pm 0.29) \times 10^{6}$ & $(6.78 \pm 0.47) \times 10^{6}$ \\
Fungi & & $(2.60 \pm 0.13) \times 10^{3}$ & $(7.5 \pm 0.02) \times 10^{4}$ \\
Yeast & & $(1.98 \pm 0.03) \times 10^{2}$ & $(4.82 \pm 0.24) \times 10^{5}$ \\
\hline
\end{tabular}

cutaneum and Yarrowia lipolytica have been already reported as able to remove some organic matter from effluents.

ANOVA test applied to highlight the variation of microbial counts in both investigated pilots as a function of depth showed no significant difference for total flora and fungi. However, yeast has shown a significant difference $(\mathrm{P}=0.01)$ in the S-Mixture CW.

$R S$ : Raw sand; $S$-UW: sand from $C W$ treating $U W$; $S$ Mixture sand from $C W$ treating $O M W W$

Table 4 and Fig. 6-A show that in the CW receiving UW a slight difference was noticed for total flora count as concentrations were $1.39 \times 10^{7}, 9.2 \times 10^{6}$ and $5.9 \times 10^{6} \mathrm{CFU} / \mathrm{g}$ of dry sand respectively for layers $0-10,10-20$ and $20-30 \mathrm{~cm}$. In terms of fungi and yeast, no significant difference was observed. Fungi's concentrations were $2.14 \times 10^{4}, 1.45 \times 10^{4}$ and $2.6 \times 10^{3} \mathrm{CFU} / \mathrm{g}$ of dry sand respectively for $0-10,10-20$ and 20-30-cm layers. Yeast concentrations in the same layers were respectively $3.1 \times 10^{4}, 4.33 \times 10^{4}$ and $1.98 \times 10^{2} \mathrm{CFU} / \mathrm{g}$ of dry sand.

Figure 6-B shows that in $\mathrm{CW}$ treating the mixture, the highest concentrations of total flora, fungi and yeast are located in the first $20 \mathrm{~cm}$ with a massive increase $(\times 10)$ in the content of yeast as it increased from $3.43 \times 10^{6}$ to $1.37 \times 10^{7}$ CFU/g of dry sand. This increase can be explained as high concentrations of yeast can be imported by OMWW since yeast are the dominant microorganisms in OMWW when compared to other groups of microorganisms (Amaral et al. 2010; Grafias et al. 2010). Moreover, compared to other microbial groups, yeast have a much higher growth rate and they can resist to the toxicity of phenolic compounds (Mendonça et al. 2004).

In the literature, the high concentration of microbial groups in the first $20 \mathrm{~cm}$ was confirmed by the authors demonstrating that diversity index was highest in the top layer $(0-10 \mathrm{~cm})$, and that the relative abundances of bacteria and fungi generally decreased significantly at 0-40 cm depths (Li et al. 2017; Yao et al. 2018). This increase is usually related to the abundant presence of nutritive substances (Nitrogen, Carbon) indispensable for microorganism growth in the surface. However, since the results in the current study demonstrate that the concentration of nutritive substances in all three layers is more or less similar (Fig. 3), we tend to believe that this high abundance could be associated to the physical barrier played by fine sand particles which can block the microorganism in the first layers. Hence, in the first $20 \mathrm{~cm}$ the direct addition by the OMWW and to the fast growth process of yeast can explain the high values observed in the first $20 \mathrm{~cm}$ layer.

\section{Conclusion}

The current work studied the behaviours of physicochemical and microbiological characteristics of a vertical flow 
Fig. 6 Evolution of total flora, fungi and yeast in (A) S-UW and (B) S-Mixture at different depths

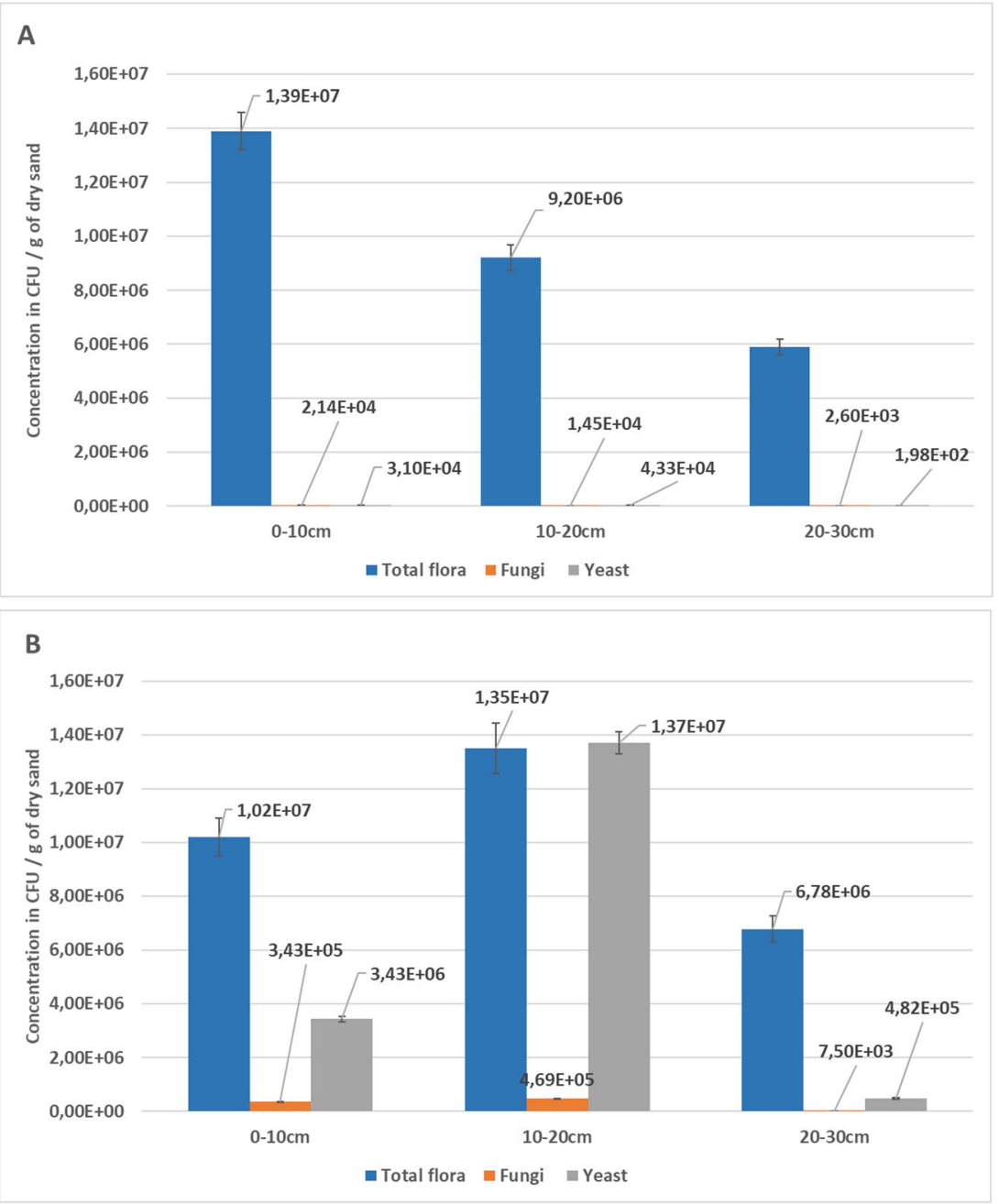

constructed wetland substrate after treating a mixture of urban and olive mill wastewaters.

The effects of OMWW application on substrate physicochemical parameters were observed at all depths. Compared to the raw substrate and the substrate from conventional $\mathrm{CW}$, higher concentrations of EC, TDS, TOC, TN, C/N and total polyphenols were detected in the substrate of the $\mathrm{CW}$ treating the OMWW. These concentrations were more or less similar at all depths. For microbiological parameters, a general increase of total flora, fungi and yeasts was observed in $\mathrm{CW}$ treating the OMWW at all depths in respect to the concentrations detected in the conventional $\mathrm{CW}$ substrate. A significant increase in the yeast community was observed in the $\mathrm{CW}$ treating the OMWW at a depth of $10-20 \mathrm{~cm}$.

From the data collected in this study, we can conclude that changes can occur in the physicochemical and microbiological parameters of the substrate when treating OMWW in CW. However, these changes cause no damage to the CW degradation mechanisms as an increase in the removal efficiency was observed in respect to the conventional CW whilst working under the same conditions.

Acknowledgements This work was financed by the IRRIGATIO Project (ERANETMED-13-069, 2014 call, seventh framework program). A big thank to the National Centre for Studies and Research on Water and Energy (Cadi Ayyad University) and the Pole of competences on Water and Environment (PC2E) for their technical and financial support to this work.

Availability of data and materials All data generated or analysed during this study are included in this published article.

Author contribution Conceptualization, methodology, validation, formal analysis, writing the original draft: Ayoub EL GHADRAOUI and Chaima SAF; Project administration, formal analysis, writing the original draft: Naaila OUAZZANI. Investigation, visualization: Abdelaali AHMALI, Abdessamed HEJJAJ and Faissal AZIZ; Conceptualization, writing - review and editing: Massimo DEL BUBBA; Resources, supervision, writing - review and editing: Laila MANDI. All authors read and approved the final manuscript. 
Funding This work was financed by the IRRIGATIO Project (ERANETMED-13-069, 2014 call, 7th framework program).

\section{Declarations}

Ethics approval and consent to participate Not applicable.

Consent for publication Not applicable.

Competing interests The authors declare no competing interests.

\section{References}

Achak M, Hafidi A, Ouazzani N, Sayadi S, Mandi L (2009) Low cost biosorbent "banana peel" for the removal of phenolic compounds from olive mill wastewater: kinetic and equilibrium studies. J Hazard Mater 166:117-125. https://doi.org/10.1016/j.jhazmat. 2008.11 .036

Achak M, Ouazzani N, Mandi L (2011) Organic pollutants removal from olive mill wastewater by a combined system of a sand filter and an aquatic plant system. Jour Sci l'Eau 24:35-51. https://doi.org/10. $7202 / 045826$ ar

Achak M, Boumya W, Ouazzani N, Mandi L (2019) Preliminary evaluation of constructed wetlands for nutrients removal from olive mill wastewater (OMW) after passing through a sand filter. Ecol Eng 136:141-151. https://doi.org/10.1016/j.ecoleng.2019.06.007

AFNOR (1982) Recueil de norme française : Eau, méthodes d'essai, Paris Édition, Paris

Ahmali A, Mandi L, Loutfi K, el Ghadraoui A, el Mansour TE, el Kerroumi A, Hejjaj A, del Bubba M, Ouazzani N (2020) Agrophysiological responses of Koroneiki olive trees (Olea europaea L.) irrigated by crude and treated mixture of olive mill and urban wastewaters. Sci Hortic (Amsterdam) 263:109101. https://doi.org/ 10.1016/j.scienta.2019.109101

Aissam H (2003) Etude des effluents des huileries de la ville de Fès (margines): Caractérisation, Biotraitement et Valorisation. Thèse Doctorat Nationale, Faculté des sciences de Fès. 172

Aktas ES, Imre S, Ersoy L (2001) Characterization and lime treatment of olive mill wastewater. Water Res 35:2336-2340. https://doi.org/10. 1016/S0043-1354(00)00490-5

Amaral C, Anjos R, Pais C, Musculo A (2010) Bioremediation of olive mill wastewaters with fungi. Terr Aquat Environ Toxicol 4:45-56

Aubert G (1978) Méthodes d'analyse des sols. Éditions C.R.D.P., Marseille, 502 France 360

Ayed L, Assas N, Sayadi S, Hamdi M (2005) Involvement of lignin peroxidase in the decolourization of black olive mill wastewaters by Geotrichum candidum. Lett Appl Microbiol 40:7-11. https:// doi.org/10.1111/j.1472-765X.2004.01626.x

Azbar N, Bayram A, Filibeli A et al (2004) A review of waste management options in olive oil production. Crit Rev Environ Sci Technol 34:209-247. https://doi.org/10.1080/10643380490279932

Barbera AC, Maucieri C, Cavallaro V, Ioppolo A, Spagna G (2013) Effects of spreading olive mill wastewater on soil properties and crops, a review. Agric Water Manag 119:43-53. https://doi.org/10. 1016/j.agwat.2012.12.009

Ben Sassi A, Boularbah A, Jaouad A, Walker G, Boussaid A (2006) A comparison of Olive oil Mill Wastewaters (OMW) from three different processes in Morocco. Process Biochem 41:74-78. https:// doi.org/10.1016/j.procbio.2005.03.074

Bruzzoniti MC, Rivoira L, Castiglioni M, el Ghadraoui A, Ahmali A, el Mansour TEH, Mandi L, Ouazzani N, del Bubba M (2020) Extraction of polycyclic aromatic hydrocarbons and polychlorinated biphenyls from urban and olive mill wastewaters intended for reuse in agricultural irrigation. J AOAC Int 103:382-391. https://doi.org/ 10.5740/jaoacint.19-0257

Calheiros CSC, Rangel AOSS, Castro PML (2007) Constructed wetland systems vegetated with different plants applied to the treatment of tannery wastewater. Water Res 41:1790-1798. https://doi.org/10. 1016/j.watres.2007.01.012

Chatzistathis T, Koutsos T (2017) Olive mill wastewater as a source of organic matter, water and nutrients for restoration of degraded soils and for crops managed with sustainable systems. AgricWater Manag 190:55-64

Chehab H, Tekaya M, Ouhibi M, Gouiaa M, Zakhama H, Mahjoub Z, Laamari S, Sfina H, Chihaoui B, Boujnah D, Mechri B (2019) Effects of compost, olive mill wastewater and legume cover cropson soil characteristics, tree performance and oil quality of olive trees cv.Chemlali grown under organic farming system. Sci Hortic 253: 163-171. https://doi.org/10.1016/j.scienta.2019.04.039

Chiesura A, Marano V, De Francesco P, Maraglino A (2005) Verso la sostenibilità della filiera olivicola: trattamento, recupero e valorizzazione dei sottoprodotti oleari. UNASCO, Roma

Chyan JM, Senoro DB, Lin CJ, Chen PJ, Chen IM (2013) A novel biofilm carrier for pollutant removal in a constructed wetland based on waste rubber tire chips. Int Biodeterior Biodegrad 85:638-645. https://doi.org/10.1016/j.ibiod.2013.04.010

Corwin DL, Yemoto K (2020) Salinity: electrical conductivity and total dissolved solids. Soil Sci Soc Am J 84:1442-1461. https://doi.org/ 10.1002/saj2.20154

Del Bubba M, Checchini L, Pifferi C et al (2004) Olive mill wastewater treatment by a pilot-scale subsurface horizontal flow (SSF-h) constructed wetland. Ann Chim 94:875-887. https://doi.org/10.1002/ adic. 200490110

Di Serio MG, Lanza B, Mucciarella MR et al (2008) Effects of olive mill wastewater spreading on the physico-chemical and microbiological characteristics of soil. Int Biodeterior Biodegrad 62:403-407. https://doi.org/10.1016/j.ibiod.2008.03.006

El Ghadraoui A, Ouazzani N, Ahmali A et al (2020) Treatment of olive mill and municipal wastewater mixture by pilot scale vertical flow constructed wetland. Desalin Water Treat 198:126-139. https://doi. org/10.5004/dwt.2020.26009

El Hassani FZ, Fadile A, Faouzi M et al (2020) The long term effect of Olive Mill Wastewater (OMW) on organic matter humification in a semi-arid soil. Heliyon 6:e03181. https://doi.org/10.1016/j.heliyon. 2020.e03181

Elmansour TE, Mandi L, Ahmali A, Elghadraoui A, Aziz F, Hejjaj A, del Bubba M, Ouazzani N (2020) Effect of polyphenols on activated sludge biomass during the treatment of highly diluted olive mill wastewaters: biomass dynamics and purifying performances. Water Sci Technol 82:1416-1429. https://doi.org/10.2166/wst. 2020.423

Galanakis C M (2017) Olive mill waste: recent advances for suitable management. Academic presse, an imprint of Elsevier

Grafias P, Xekoukoulotakis NP, Mantzavinos D, Diamadopoulos E (2010) Pilot treatment of olive pomace leachate by vertical-flow constructed wetland and electrochemical oxidation: an efficient hybrid process. Water Res 44:2773-2780. https://doi.org/10.1016/j. watres.2010.02.015

Herouvim E, Akratos CS, Tekerlekopoulou A, Vayenas DV (2011) Treatment of olive mill wastewater in pilot-scale vertical flow constructed wetlands. Ecol Eng 37:931-939. https://doi.org/10.1016/j. ecoleng.2011.01.018

Kapellakis IE, Tsagarakis KP, Crowther JC (2008) Olive oil history, production and by-product management. Rev Environ Sci Biotechnol 7:1-26. https://doi.org/10.1007/s11157-007-9120-9

Kapellakis IE, Paranychianakis NV, Tsagarakis KP, Angelakis AN (2012) Treatment of olive mill wastewater with constructed wetlands. Water 4:260-271. https://doi.org/10.3390/w4010260 
Karpouzas DG, Ntougias S, Iskidou E, Rousidou C, Papadopoulou KK, Zervakis GI, Ehaliotis C (2010) Olive mill wastewater affects the structure of soil bacterial communities. Appl Soil Ecol 45:101-111. https://doi.org/10.1016/j.apsoil.2010.03.002

Kleinmann RLP, Girts MA (1987) Acid mine water treatment in wetlands: an overview of an emergent technology. In: Aquatic plants for water treatment and resource recovery (edited by K. R. Reddy and W. H. Smith). Magnolia Publishing Inc., Orlando, Fla. 471-478

Knight RL, Payne VWE, Borer RE et al (2000) Constructed wetlands for livestock wastewater management. Ecol Eng 15:41-55. https://doi. org/10.1016/S0925-8574(99)00034-8

Laura F, Marianna G, Rocío P (2021) Joan G (2021) Promotion of fullscale constructed wetlands in the wine sector: comparison of greenhouse gas emissions with activated sludge systems. Sci Total Environ 770:145326. https://doi.org/10.1016/j.scitotenv.2021. 145326

Li X, Sun J, Wang H, Li X, Wang J, Zhang H (2017) Changes in the soil microbial phospholipid fatty acid profile with depth in three soil types of paddy fields in China. Geoderma 290:69-74. https://doi. org/10.1016/j.geoderma.2016.11.006

Li X, Wu S, Yang C, Zeng G (2020) Microalgal and duckweed based constructed wetlands for swine wastewater treatment: a review. Bioresour Technol 318:123858. https://doi.org/10.1016/j.biortech. 2020.123858

Macheix JJ, Fleuriet A, Billot J (2018) Fruit phenolics. CRC Press, 18 390

Magdich S, Abid W, Boukhris M, Rouina BB, Ammar E (2016) Effects of long-term olive mill wastewater spreading on the physiological and biochemical responses of adult Chemlali olive trees (Olea europaea L.). Ecol Eng 97:122-129. https://doi.org/10.1016/j. ecoleng.2016.09.004

Mantzavinos D, Kalogerakis N (2005) Treatment of olive mill effluents: Part I. Organic matter degradation by chemical and biological processes - an overview. Environ Int 31:289-295. https://doi.org/10. 1016/j.envint.2004.10.005

Meftah O, Guergueb Z, Braham M, Sayadi S, Mekki A (2019) Long term effects of olive mill wastewaters application on soil properties and phenolic compounds migration under arid climate. Agric Water Manag 212:119-125. https://doi.org/10.1016/j.agwat.2018.07.029

Mekki A, Dhouib A, Sayadi S (2007) Polyphenols dynamics and phytotoxicity in a soil amended by olive mill wastewaters. J Environ Manag 84:134-140. https://doi.org/10.1016/j.jenvman.2006.05.015

Mendonça E, Martins A, Anselmo AM (2004) Biodegradation of natural phenolic compounds as single and mixed substrates by Fusarium flocciferum. Electron J Biotechnol 7:37-44. https://doi.org/10.2225/ vol7-issue1-fulltext-3

Michailides M, Tatoulis T, Sultana MY, Tekerlekopoulou A, Konstantinou I, Akratos SC, Pavlou S, Vayenas D V. (2015) Izgradnja vestacke mocvare $\mathrm{u}$ cilju tretiranja otpadne vode nastale usled rada mlina za masline. Hem Ind 69:577-583. https://doi.org/ 10.2298/HEMIND140820076M

Morillo JA, Aguilera M, Antízar-Ladislao B, Fuentes S, RamosCormenzana A, Russell NJ, Monteoliva-Sánchez M (2008) Molecular microbial and chemical investigation of the bioremediation of two-phase olive mill waste using laboratory-scale bioreactors. Appl Microbiol Biotechnol 79:309-317. https://doi.org/10. 1007/s00253-008-1422-5

Muktadirul Bari Chowdhury AKM, Akratos CS, Vayenas DV, Pavlou S (2013) Olive mill waste composting: a review. Int Biodeterior Biodegrad 85:108-119. https://doi.org/10.1016/j.ibiod.2013.06.019

Mutabaruka R, Hairiah K, Cadisch G (2007) Microbial degradation of hydrolysable and condensed tannin polyphenol-protein complexes in soils from different land-use histories. Soil Biol Biochem 39: 1479-1492. https://doi.org/10.1016/j.soilbio.2006.12.036
Ouzounidou G, Zervakis G, Gaitis F (2010) Raw and microbiologically detoxified olive mill waste and their impact on plant growth. Terr Aquat Environ Toxicol 4:21-38

Paraskeva P, Diamadopoulos E (2006) Technologies for olive mill wastewater (OMW) treatment: a review. J Chem Technol Biotechnol 81: 1475-1485. https://doi.org/10.1002/jctb.1553

Paredes MJ, Moreno E, Ramos-Cormenzana A, Martinez J (1987) Characteristics of soil after pollution with waste waters from olive oil extraction plants. Chemosphere 16:1557-1564. https://doi.org/ 10.1016/0045-6535(87)90096-8

Park WH, Polprasert C (2008) Phosphorus adsorption characteristics of oyster shells and alum sludge and their application for nutrient control in constructed wetland system. J Environ Sci Heal Part A Toxic Hazardous Subst Environ Eng 43:511-517. https://doi.org/10.1080/ 10934520701796440

Pelendridou K, Michailides MK, Zagklis DP, Tekerlekopoulou AG, Paraskeva CA, Vayenas DV (2014) Treatment of olive mill wastewater using a coagulation-flocculation process either as a single step or as post-treatment after aerobic biological treatment. J Chem Technol Biotechnol 89:1866-1874. https://doi.org/10.1002/jctb. 4269

Piotrowska A, Rao MA, Scotti R, Gianfreda L (2011) Changes in soil chemical and biochemical properties following amendment with crude and dephenolized olive mill waste water (OMW). Geoderma 161:8-17. https://doi.org/10.1016/j.geoderma.2010.11.011

Rodier J, Legube B, Merlet N (2009) L'analyse des eaux. 1600 Paris: (9 ed.), Dunod

Rousidou C, Papadopoulou K, Zervakis G, Singh BK, Ehaliotis C, Karpouzas DG (2010) Repeated application of diluted olive mill wastewater induces changes in the structure of the soil microbial community. Eur J Soil Biol 46:34-40. https://doi.org/10.1016/j. ejsobi.2009.10.004

Saadi I, Laor Y, Raviv M, Medina S (2007) Land spreading of olive mill wastewater: effects on soil microbial activity and potential phytotoxicity. Chemosphere 66:75-83. https://doi.org/10.1016/j. chemosphere.2006.05.019

Saeed T, Afrin R, Al MA, Sun G (2012) Treatment of tannery wastewater in a pilot-scale hybrid constructed wetland system in Bangladesh. Chemosphere 88:1065-1073. https://doi.org/10.1016/j. chemosphere.2012.04.055

Shi X, Fan J, Zhang J, Shen Y (2017) Enhanced phosphorus removal in intermittently aerated constructed wetlands filled with various construction wastes. Environ Sci Pollut Res 24:22524-22534. https:// doi.org/10.1007/s11356-017-9870-z

Sinsabaugh RL (2010) Phenol oxidase, peroxidase and organic matter dynamics of soil. Soil Biol Biochem 42:391-404. https://doi.org/ 10.1016/j.soilbio.2009.10.014

Stefanakis A, Akratos CS, Tsihrintzis VA (2014) Vertical Flow constructed wetlands: eco-engineering systems for wastewater and sludge treatment. 1st edition:392. https://doi.org/10.1016/C2012-001288-4

Tatoulis T, Stefanakis A, Frontistis Z, Akratos CS, Tekerlekopoulou AG, Mantzavinos D, Vayenas DV (2017) Treatment of table olive washing water using trickling filters, constructed wetlands and electrooxidation. Environ Sci Pollut Res 24:1085-1092. https:// doi.org/10.1007/s11356-016-7058-6

Tiglyene S, Mandi L, Jaouad A (2005) Removal of chromium from tannery wastewater by vertical infiltration reed beds. Journal of Water Sciences 18(2):177-198

Wang HX, Xu JL, Sheng LX, Liu XJ (2018) A review of research on substrate materials for constructed wetlands. Materials Science Forum, pp 917-929

Yalcuk A, Pakdil NB, Turan SY (2010) Performance evaluation on the treatment of olive mill waste water in vertical subsurface flow constructed wetlands. Desalination 262:209-214. https://doi.org/10. 1016/j.desal.2010.06.013 
Yao X, Zhang N, Zeng H, Wang W (2018) Effects of soil depth and plant-soil interaction on microbial community in temperate grasslands of northern China. Sci Total Environ 630:96-102. https://doi. org/10.1016/j.scitotenv.2018.02.155

Yazdani V, Golestani HA (2019) Advanced treatment of dairy industrial wastewater using vertical flow constructed wetlands. Desalin Water Treat 162:149-155. https://doi.org/10.5004/dwt.2019.24335

Zhao C, Long J, Liao H, Zheng C, Li J, Liu L, Zhang M (2019) Dynamics of soil microbial communities following vegetation succession in a karst mountain ecosystem. Southwest China Sci Rep 9:2160. https:// doi.org/10.1038/s41598-018-36886-Z

Zhu WL, Cui LH, Ouyang Y et al (2011) Kinetic adsorption of ammonium nitrogen by substrate materials for constructed wetlands.
Pedosphere 21:454-463. https://doi.org/10.1016/S1002-0160(11) 60147-1

AFNOR (1985) Recueil de norme française : Eau, méthodes d'essai, Paris Édition, Paris

AFNOR (1988) Recueil de norme française : Eau, méthodes d'essai, Paris Édition, Paris

AFNOR (1997) Recueil de norme française : Eau, méthodes d'essai, 2ème édition, Paris Édition, Paris

Publisher's note Springer Nature remains neutral with regard to jurisdictional claims in published maps and institutional affiliations. 